Research Article

\title{
Impact of the Reduction of VAT Rate on Southeast Coastal Real Estate Enterprises
}

\author{
Yu Liu $\mathbb{D}^{1},{ }^{1}$ Linghui Kong $\mathbb{D D}^{2}{ }^{2}$ and Yanhua Zhang ${ }^{1}$ \\ ${ }^{1}$ School of Economics and Management, Communication University of China, Beijing 100024, China \\ ${ }^{2}$ School of Accounting, Guangdong University of Finance \& Economics, Guangzhou 510320, China \\ Correspondence should be addressed to Linghui Kong; 20131818@gdufe.edu.cn
}

Received 25 October 2021; Revised 11 November 2021; Accepted 15 November 2021; Published 30 November 2021

Academic Editor: Daqing Gong

Copyright (C) 2021 Yu Liu et al. This is an open access article distributed under the Creative Commons Attribution License, which permits unrestricted use, distribution, and reproduction in any medium, provided the original work is properly cited.

\begin{abstract}
This paper takes the southeast coastal real estate listed enterprises that have been at the forefront of China's reform for many years as the research object. Through theoretical analysis and descriptive statistical analysis, it studies the impact of the reduction of VAT (value-added tax) rate in 2019 on the southeast coastal listed real estate enterprises from the perspectives of sales revenue, costs, tax burden, profit, and cash flow. The overall operating tax rate has shown a volatile downward trend; the average operating income level has shown a volatile upward trend; the purchase cost has decreased slightly and the change was not significant; the total profits of enterprises have shown a cyclical upward trend. Due to the impact of the real estate purchase restriction policy and financing environment in recent years, the reduction of tax rate has an effective but not significant impact on the enterprise cash flow. Overall, the tax rate reduction still has a positive impact on enterprises. Combined with the problems in the process of policy implementation, this paper puts forward that those enterprises should make scientific and reasonable tax planning, pay attention to the management of purchase and sales contracts and the mode of cooperation with upstream enterprises, regulate taxation to reduce tax-related risks, improve the management level of enterprises, and establish an industry finance integration system. At the national policy level, there is limited room and effect for the reduction of the VAT rate, and more preferential tax relief policies should be given directly, not limited to VAT, but can be extended to corporate income tax. In this way, that could improve the effectiveness of the tax reduction policy in the southeast coastal real estate industry and provide a reference for relevant industries in other regions to solve similar problems.
\end{abstract}

\section{Introduction and Literature Review}

1.1. Research Background. Value-added tax is the main tax in China, and its unique chain deduction mechanism can effectively promote economic reform and regulate industrial development. Since the 2012 "replace business with VAT" pilot reform, the phenomenon of double taxation has been effectively eliminated. However, structural tax reductions have increased the tax burden of general taxpayers in some industries, such as construction and real estate. After the State Administration of Taxation issued a notice on further tax and fee reductions in 2018, the reduction of the valueadded tax rate became the main keynote of the government's macrocontrol; in 2019, the reduction of the value-added tax rate was increased again, from the original $16 \%$ and $10 \%$ to
$13 \%$ and $9 \%$, effectively stimulating the market demand of the tertiary industry.

1.2. Research Objective. The real estate industry is in the middle of the national economic chain and has a strong correlation effect. The prosperity of the real estate industry can effectively drive the prosperity of many industries. Therefore, this paper takes the southeast coastal real estate listed enterprises that have been at the forefront of China's reform for many years as the research object and studies the impact of the reduction of value-added tax rate on those enterprises in 2019 from the perspectives of sales revenue, costs, tax burden, profit, and cash flow through theoretical and empirical analysis. We hope this paper can provide a 
reference for relevant industries in other regions to solve similar problems.

1.3. Research Meaning. The operation and construction cycle of the real estate industry is long, and its typical presale mode leads to a serious mismatch between the output and input of enterprise value-added tax, which leads to the fact that real estate enterprises cannot fully enjoy the advantages of value-added tax. There are few studies on the impact of VAT reform on the real estate industry. This study enriches the perspective of VAT research to a certain extent. Therefore, it is of theoretical and practical significance to analyze the impact of the reduction of value-added tax rate on real estate enterprises.

1.4. Literature Review. In recent years, domestic scholars have not been in a small number of theories and empirical researches of VAT reform, and this paper combs from the following three aspects.

\subsubsection{The Impact of VAT Reform on Enterprise Tax Burden,} Investment, and Innovation. China's VAT reforms have achieved remarkable results. Through the empirical analysis of various industries and enterprises in China, it is found that China's VAT reform initiatives have significantly affected the industries/enterprises tax burden: the effective tax rate in various industries has dropped by $1 \%-10 \%$ [1]. Although the preferential policy of VAT has significantly increased the enterprise income tax burden and the actual total tax burden of general taxpayers, it has reduced the actual tax burden of small-scale taxpayers; if the VAT retention tax rebate system is established and the actual deductible rate of enterprises is improved, the burden of VAT can also be reduced to a certain extent [2]. However, the uncertainty of fiscal and tax policies may increase the tax burden of enterprises by increasing the financial pressure of the government. When the tax quota is higher, this effect is stronger. Therefore, maintaining the transparency and stability of policies will help to reduce the tax burden [3].

By analyzing the data of Chinese listed companies to study the tax acceleration of enterprise upgrading, it is found that the VAT reforms can encourage technology upgrading, but there is no significant increase in fixed investment, and the number of employees has decreased significantly. Tax reduction and tax incentives are important ways for enterprises to innovate investment, patent application, and realize enterprise upgrading $[4,5]$. Ding et al. [6] studied that the value-added tax reform promoted the innovation performance of governance group companies by expanding the company's fixed asset investment and reducing the company's debt ratio. In addition, the value-added tax reform has a greater impact on the innovation of export enterprises and nonstate-owned enterprises. Howell [7] studied the relationship between Chinese enterprise innovation activities, financing constraints, and enterprise tax reform. In the case of financial constraints, reducing the corporate tax burden of private enterprises will stimulate the sales of new products and processes. Fang et al. [8] discussed how to widely implement the reform of "simplification of administration, decentralization, and tax reduction" in China's service industry. Using the provincial panel data set from 2004 to 2013, it is verified that the reform of "streamlining administration and tax reduction" should be carried out according to different regions, times, and industry conditions.

\subsubsection{The Impact of "Replacing BT with VAT" on Enterprises} and Industries. Huang et al. [9] studied the impact of the transformation from business tax (BT) to value-added tax (VAT) on the performance of Chinese transportation enterprises and tested the impact of 49 listed companies by using the double difference model. The results show that the VAT reform has a positive impact on the profitability and growth ability of transportation enterprises but has no significant impact on the solvency and operation ability of enterprises. Through the establishment of the panel data model for descriptive and regression analysis, Ai and Fan [10] studied the impact of VAT reform on the financial performance of listed companies in the real estate industry. The results show that, after the policy reform, the change of turnover tax burden is significantly negatively correlated with the company's financial performance and the proportion of outsourcing production cost in the total operating cost is significantly positively correlated with the company's financial performance, while there is no significant correlation between the proportion of new fixed assets in the initial fixed assets and its financial performance. Theoretical analysis and practical investigation show that replacing BT with VAT has a dual impact on the tax burden of enterprises: on the one hand, it will significantly reduce the total tax burden of small taxpayers; on the other hand, for ordinary taxpayers, the change of total tax burden is uncertain. The average treatment effect of the pilot expansion of VAT on the total tax burden of ordinary taxpayers is not significant in the set sample. In addition, it shows that there is no heterogeneity between transportation industry and modern service industry, but the pilot effect varies according to deductible items. In particular, companies with higher intermediate input rate have a stronger tax reduction effect [11].

Tian and $\mathrm{Hu}$ [12] constructed CGE model to study the dynamic changes of industry tax burden after tax system reform. The results show that, in the short term, although the government designs the tax rate to balance the tax burden of industries changing from BT to VAT, in the long run, the tax burden of some industries will still rise. After replacing BT with VAT, the real estate industry known as the foundation of the national economy will be affected by tax reform, which is reflected in tax burden, cost, house price, profit, and cash flow [13]. In addition, through empirical data, it is found that replacing BT with VAT has promoted the improvement of the comprehensive financial efficiency of Chinese real estate listed companies, but the government still needs to continuously improve and adjust relevant policies, and the academic community needs to continue to pay attention to the effect of fiscal and tax policies [14]. 
1.4.3. Influence of VAT Reform Measures in 2019. Under the background of the global economic recession, with the increase of downward pressure and the rise of trade protectionism, the Chinese government has made reform progress in adjusting the industrial structure. A series of VAT reform measures launched in 2019 have improved effective supply and stimulated domestic consumption [15]. Value-added tax reduction in 2019 is an important tool to cultivate a new driving force for economic development, which has a significant impact on local fiscal pressure: local fiscal pressure has increased from 0.342 to 0.435 . Therefore, policy-making departments need to find a balance between optimizing tax structure and reducing fiscal pressure [16].

To sum up, studies at home and abroad mainly focus on the impact of China's VAT reform on enterprise tax burden, investment, and innovation, as well as the impact and effect of replacing BT with VAT on different industries. The impact on the reduction of the value-added tax rate is more focused on the macro, and the regional research on the reduction of the valueadded tax rate on real estate enterprises is basically blank.

\section{Theoretical Analysis: The Impact of the Lower VAT Rate on Real Estate Companies}

2.1. Impact of Sales Revenue. Enterprise sales revenue is not only the main component of enterprise profits but also the main basis for measuring enterprise value-added tax. After replacing business tax with value-added tax, the sales volume of value-added tax calculated by real estate enterprises is the total price and other expenses obtained by ordinary taxpayers from selling their developed real estate projects minus the land price actually paid when transferring land. Due to the decline of the value-added tax rate and the decline of actual value-added tax, on the one hand, the increase of operating income of real estate enterprises depends on the sales of real estate commodities. In other words, due to the high concentration of the industry in which the real estate enterprises are located, the supply of real estate commodities is limited, and the real estate developers have relatively high pricing power. The decline of the value-added tax burden of enterprises stimulates the sales of real estate commodities, resulting in the increase of the sales volume of real estate commodities, thus increasing the sales revenue. When other financial indicators remain unchanged, there are two situations in which the sales income of real estate companies changes. First, under tax-exclusive transactions, when the tax-exclusive house price remains unchanged, the reduction of the value-added tax rate will not affect the sales revenue disclosed in the financial statements of real estate companies; second, under the tax-included transaction, when the taxincluded house price remains unchanged, the sales of the company income will increase. For example, the company's tax-included contract price is $A$, and when other financial indicators remain unchanged, the increase in actual sales revenue is

$$
\frac{A}{(1+9 \%)}-\frac{A}{1+10 \%}=A \times 0.83 \% .
$$

Regardless of other factors, when the decline of the value-added tax rate makes the tax-included contract price unchanged, the output tax amount will decrease, and the decreased tax amount will be equivalent to the increase in sales revenue.

2.2. Impact of Costs. The costs of real estate development companies mainly refer to the costs of real estate development products, including various expenses incurred by real estate development companies in the development process. Based on the financial perspective, it mainly includes land development cost, housing development cost, and supporting facilities development cost. For the costs related to value-added tax in the enterprise's costs and expenses, due to the deduction of the input tax such as purchased materials from the VAT paid to the state in the "Business Tax Replaced with VAT," the operating cost has been reduced, and since the business tax that previously entered the "taxes and surcharges" is not paid, the "taxes and surcharges" that entered the current profit and loss have been reduced accordingly.

There are two pricing methods for transactions between real estate companies and upstream suppliers: first, pricing is based on tax-exclusive costs; second, pricing is based on taxincluded costs [3]. In the case of excluding tax cost pricing, the reduction of the value-added tax rate directly leads to a reduction in the deductible input tax of business procurement and other businesses, but it does not affect the procurement costs disclosed in the statement. In the entire real estate industry chain, if upstream suppliers have a high degree of monopoly and strong bargaining power when the value-added tax rate is reduced, the tax-included contract price remains unchanged. After deduction of the deductible input tax, no taxincluded prices are equivalent to rising in disguise. For example, the tax-included purchase contract price of a company is $B$, and when the $16 \%$ tax rate is applied to the purchase of goods, such as building materials and electrical equipment, after the tax rate is reduced to $13 \%$, due to the reduction in input tax, the increase in tax-free purchase costs is

$$
\frac{B}{(1+13 \%)}-\frac{B}{(1+16 \%)}=B \times 2.29 \% \text {. }
$$

Similarly, for the purchase of transportation services, construction services, and so on, with an applicable tax rate of $10 \%$, the tax-exclusive cost increase is

$$
\frac{B}{(1+9 \%)}-\frac{B}{(1+10 \%)}=B \times 0.83 \% \text {. }
$$

Since the tax rate applicable to the $6 \%$ tax rate of financial services and other production and living service industries remains unchanged and the input tax amount remains unchanged, the related costs and expenses will not be affected.

2.3. Impact of VAT Burden. "The tax reduction bonus released by the value-added tax reform meets the urgent requirements of the supply-side structural reform, provides 
greater development space for suppliers, and also has a positive impact on stimulating consumption and promoting consumption upgrading."

The current new projects of real estate companies use the tax calculation method of general taxpayers to calculate and pay value-added tax. Because the tax calculation method of value-added tax is input deduction, the value-added tax of real estate companies will generally decline with the adjustment of the tax rate. First, for new real estate projects, according to the time when the tax obligation occurs, after the time when the tax rate is adjusted, the tax needs to be calculated according to the new value-added tax rate, the output tax decreases with the reduction of the value-added tax rate. Second, the sales contracts signed by real estate enterprises include contracts priced without tax and within tax. When the contract is priced without tax, usually the output is much greater than the input, and the final value-added tax of the enterprise will also decrease. As for the contract priced within tax, when the VAT rate is reduced, the output and input both decrease. The reduction of the input tax is greater; however, the output is often greater than the input, so the VAT payable is also lower than that before the reduction of the tax rate, but the specific decline range depends on the bargaining power between the real estate enterprises and the upstream and downstream.

2.4. Impact of Profit. The reduction of value-added tax rate mainly affects the profit level of enterprises through the changes in sales revenue, costs, land deductions, taxes, and surcharges. When the contract is priced at a price excluding tax, the change of the VAT tax rate mainly affects the profit and loss of the enterprise through the impact on taxes and surcharges. When the contract is priced at a price including tax, different enterprises have different operating efficiency in the sales and purchase links, and the impact of tax rate reduction on the profit and loss of the enterprise's sales business is also different. Below, based on the above hypothetical data, the change of enterprise sales profit and loss is simplified and analyzed.

The above analysis has shown that, after the reduction of the VAT rate, the income of enterprises increased, the cost decreased, and the total profit increased, which had a positive impact on the profit and loss of sales business of real estate enterprises. Of course, there are differences in the proportion of different enterprise costs and land acquisition costs to sales revenue, and the final impact of the change of value-added tax rate on enterprise profits and losses will also be different. The final consumer pays the price including tax. In the long run, the change of tax rate will affect the price level and lead to the change of market demand. And in different industry backgrounds, the difference in bargaining power between different enterprises and upstream and downstream makes the impact of tax rate changes on enterprise sales revenue or costs different, so as to have a different impact on enterprise profits and losses. For enterprises with strong bargaining power, the difference between sales price and purchase cost is larger and the reduction of enterprise value-added tax burden is smaller, but the growth of enterprise profit and loss may be greater.

To sum up, based on the assumption of "pricing based on the within tax price and the within tax price is fixed," the impact mechanism of the decline in the VAT rate on items related to the income statement is shown in Figure 1.

2.5. Impact of Cash Flow. The long period of product construction and development in the real estate industry and the fact that upstream suppliers are mostly small-scale taxpayers make it difficult for companies to obtain special value-added tax invoices and delays in deducting input tax, which leads to the occupation of current funds [5]. When purchasing and other businesses occur, companies need to pay suppliers the purchase price that is tax-inclusive. If the purchase contract does not contain tax, b remains unchanged, and after the value-added tax rate drops, the tax-included contract payment that the company needs to pay to the supplier in the current period also decreases; that is, the company's current cash outflow decline is

$$
b \times 13 \% \text { or } 9 \%-b \times 16 \% \text { or } 10 \%=b \times 3 \% \text { or } 1 \% \text {. }
$$

In addition, presale is the most typical sales method for real estate companies. The value-added tax is paid in advance when the company receives the presale payment. Because the presales are mostly tax-inclusive, under the condition that the tax-included sales income $A$ remains unchanged, the VAT is prepaid at a tax rate of $3 \%$, and the amount of change in prepaid VAT is

$$
\frac{A}{(1+9 \%)} \times 3 \%-\frac{A}{(1+10 \%)} \times 3 \%=A \times 0.025 \% \text {. }
$$

That is, due to the $1 \%$ reduction in the value-added tax rate, real estate companies will increase their cash flow expenditure by $0.025 \%$ when they receive the presale payment.

But on the whole, the reduction of the value-added tax rate will have a positive impact on the cash flow in the daily operations of real estate companies; especially in the procurement and presale stages, the reduction of the valueadded tax rate will be fully realized and reflected in the changes in cash flow expenditures.

\section{Empirical Analysis}

3.1. Descriptive Statistics. As shown in Table 1, from the first quarter of 2018 to the third quarter of 2020, the maximum operating tax rate of listed real estate enterprises in southeast coastal areas is $11.12 \%$, the minimum is $5.57 \%$, the average is $8.38 \%$, and the standard deviation is 0.0197 . There is little difference among provinces. The maximum value of the operating profit margin is $69.12 \%$, the minimum value is $-225.35 \%$, the average value is $-16.17 \%$, and the standard deviation is 0.7756 . It can be seen that there is a large gap in operating profit margin among provinces. The maximum value of inventory turnover is 5.8787, the minimum value is 2.3258 , the average value is 3.7595 , and the standard deviation is 1.2958. The maximum value of operating revenue (RMB 100 million) is 90.6809 , the minimum value is 28.3606 , the average value is 49.9455 , and the standard deviation is 18.9512 . It can be seen that there is a large gap in operating revenue among provinces. The maximum value of inventory (RMB 100 million) is 640.6957 , the minimum value is 445.2967 , the average value is 535.7372 , and the standard deviation is 65.9843 . The maximum 


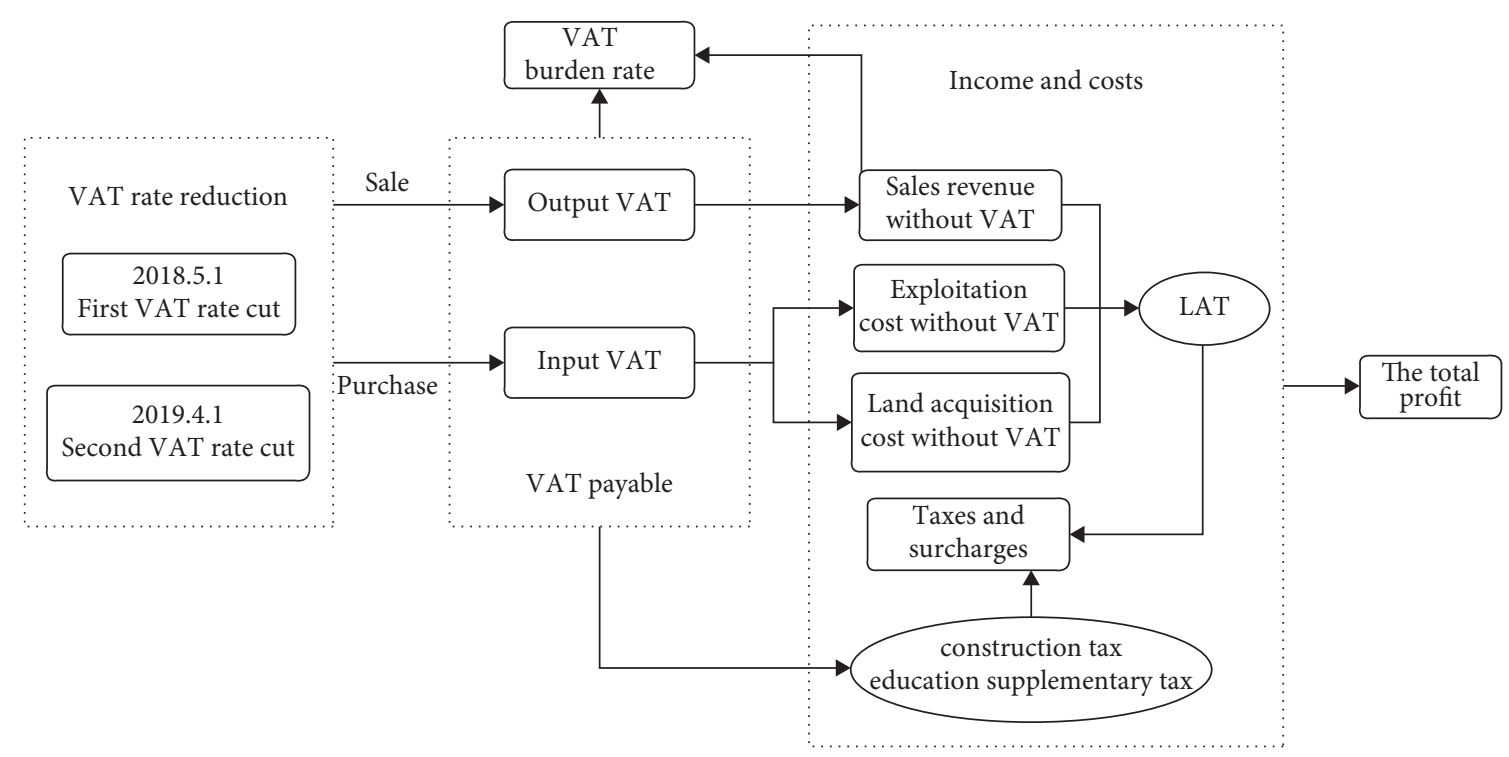

FIGURE 1: Influence mechanism.

Table 1: Descriptive statistics of listed real estate companies in the southeast coastal area (201801-202003).

\begin{tabular}{lcccc}
\hline Variable name & Max & Min & Mean & Standard deviation \\
\hline Operating tax rate & $11.12 \%$ & $5.57 \%$ & $8.35 \%$ & 0.0197 \\
Operating profit margin & $69.12 \%$ & $-225.35 \%$ & $-16.17 \%$ & 0.7756 \\
Inventory turnover & 5.8787 & 2.3258 & 3.7595 & 1.2958 \\
Operating revenue (100 million) & 90.6809 & 28.3606 & 49.9455 & 18.9512 \\
Inventory (100 million) & 640.6957 & 445.2967 & 535.7372 & 65.9843 \\
Taxes and surcharges (100 million) & 7.7110 & 1.8498 & 3.6598 & 1.8681 \\
The total profit (100 million) & 16.5877 & 4.5637 & 8.5889 & 4.0444 \\
Cash inflow from operating activities (100 million) & 100.1789 & 58.9765 & 82.2370 & 12.1910 \\
Cash outflow from operating activities (100 million) & 91.1657 & 58.8551 & 77.6613 & 9.2203 \\
\hline
\end{tabular}

value of taxes and surcharges (RMB 100 million) is 77110, the minimum value is 1.8498 , the average value is 3.6598 , and the standard deviation is 1.8681 . It can be seen that there is a large gap in taxes and surcharges among provinces. The maximum value of the total profit (RMB 100 million) is 16.5877, the minimum value is 4.5637 , the average value is 8.5889 , and the standard deviation is 4.0444 . It can be seen that there is a large gap in total profit among provinces. The maximum value of cash inflow from operating activities (RMB 100 million) is 100.1789 , the minimum value is 58.9765 , the average value is 82.2370 , and the standard deviation is 12.1910 . The maximum value of cash outflow from operating activities (RMB 100 million) is 91.1657 , the minimum value is 58.8551 , the average value is 77.6613 , and the standard deviation is 9.2203 .

The data used in this article are collected from cninfo.com; the query address is http://webapi.cninfo.com.cn/ \#/databrowse. The selection of listed companies of the real estate industry is based on listed company industry classification guidelines (2012 revision). This paper limits the "southeast coastal area": Fujian, Guangdong, Guangxi, Hainan, Jiangsu, Shanghai, and Zhejiang. All the data statistics based on enterprises in this paper are the average value of indicators in a certain province/region as a substitute for the average level of a certain indicator in a certain region; not every set of data has the same sample caliber: in the analysis according to different periods, in the ST stock situation, a different number of sample companies have been deleted, and due to the lack of certain data on the platform (https:// www.cninfo.com), it is impossible to use exactly the same sample companies when calculating each indicator. In general, for each item, the statistical sample size is between 70 and 80 .

Some calculation formulas and variable names are explained as follows:

$$
\begin{aligned}
\text { standard deviation } s & =\sqrt{\frac{\sum_{i=1}^{n}\left(x_{i}-\bar{x}\right)^{2}}{n-1},} \\
\text { operating tax rate } & =\frac{\text { taxes and surcharges }}{\text { operating revenue }}, \\
\text { operating profit margin } & =\frac{\text { operating profit }}{\text { operating revenue }}, \\
\text { inventory turnover } & =\frac{\text { operating cost }}{\text { average inventory balance }}, \\
\text { operating revenue } & =\text { revenue }+ \text { other operating income, }
\end{aligned}
$$

net balance of inventory $=$ inventory - provision for inventory.

Taxes and surcharges include consumption tax, construction tax, education surcharge, land appreciation tax, 
housing property tax, vehicle and vessel tax, urban land utilization tax, and stamp tax.

$$
\begin{aligned}
\text { the total profit }= & \text { operating profit }+ \text { non } \\
& - \text { operating income }- \text { non } \\
& - \text { operating expense. }
\end{aligned}
$$

Cash inflow from operating activities includes cash received from sales of goods or rendering services, refunds of taxes, cash received relating to other operating activities, and cash received relating to other operating activities.

Cash outflow from operating activities includes cash paid for goods or receiving services, cash paid to and on behalf of employees, tax payments, and cash paid relating to other operating activities.

\subsection{Trend Analysis}

3.2.1. Basic Situation Overview. As of November 2020, there were 80 listed real estate enterprises in the southeast coastal areas, and the distribution of their provinces is shown in Figure 2: the number of listed real estate enterprises owned by Guangdong, Shanghai, and Zhejiang has lied in the top three in the southeast coastal areas. Among them, there are 5 ST shares, and the remaining 75 are normal shares.

The data time span in Figure 3 is from the first quarter of 2018 to the third quarter of 2020. Except for the two government tax support areas of Hainan and Guangxi, the overall business tax rate of listed real estate enterprises in the southeast coastal area shows a fluctuating downward trend, and the overall average level is reduced from $8.91 \%$ to $6.53 \%$. From the perspective of regional aggregate percentage, there was a steep decline in the second quarter of 2018 and the first quarter of 2020. It is speculated that the decline was due to the lower average value of the sample caused by Hainan's tax and welfare policies and the relevant business tax relief given by the postepidemic economic recovery policies. The overall trend was a steady and lowspeed decline, which proved that after the tax rate was reduced, the ratio of business tax to operating income is gradually decreasing.

\subsubsection{Indicators That May Be Affected by the Reduction of VAT Tax Rate}

(1) Sales Revenue Trend. The followings are the difference analysis of each quarter of 2019 and the corresponding quarter of 2018 for each enterprise.

It can be seen from Table 2 that the average quarterly operating revenue of each company in 2018 was RMB 4.793 billion and that of 2019 was RMB 5.692 billion. Take the quarterly data of each enterprise in 2018 and 2019 as paired samples for Wilcoxon signed-rank test. The results are shown in Table 3.

From Table 4, $P=0.012$; that is, there is a significant difference in the quarterly operating revenue of each enterprise in 2018 and 2019 at the 95\% confidence level,

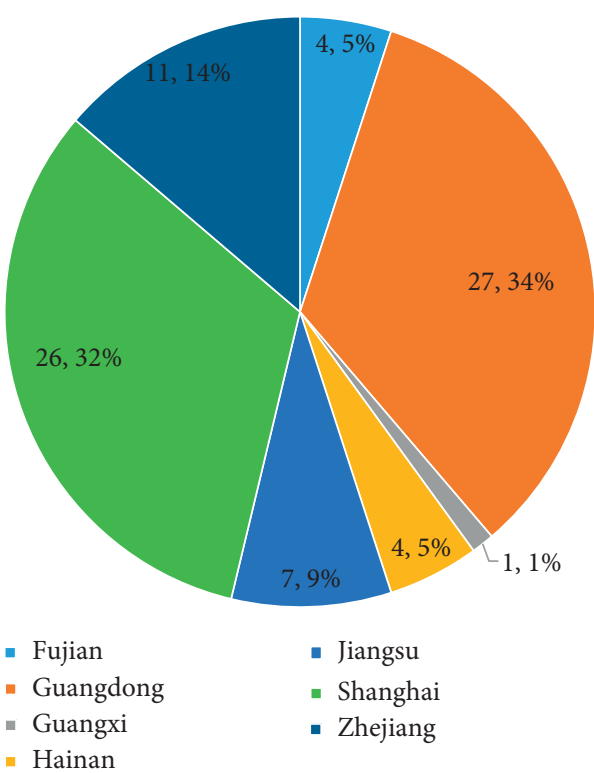

FIgURE 2: Distribution of listed real estate companies by province in the southeast coastal region.

which can be obtained from the average value of the two years. This difference is obviously higher in 2019 than in 2018.

As shown in Figure 4, the average operating revenue of listed real estate enterprises in the southeast coastal areas shows a fluctuating upward trend, and the growth of enterprises in the region as a whole and provinces is mostly concentrated in the second and fourth quarters of 2018 and 2019. The two maxima are the fourth quarter of 2018 and the fourth quarter of 2019, which are RMB 7.734 billion and RMB 9.068 billion, respectively. First of all, both extreme points appear at the end of the year. Considering the enterprise financial report adjustment mechanism, it is necessary to adjust the operating revenue, resulting in the emergence of extreme points. In addition to structural and systemic impacts, such as the economic cycle, the two tax cuts of value-added tax are likely to reduce the tax burden of enterprises, increase the corresponding proportion of business income, and promote the emergence of extreme values. Compared with the first quarter of 2018, the growth rate of operating revenue in the third quarter of 2020 was $80.71 \%$. Except for the initial endpoint value, the minimum values in other intervals were greater than the initial value. It is speculated that the tax reduction has a partial impact on the operating revenue of coastal real estate listed enterprises.

(2) Cost Trend. As shown in Figure 5, from the first quarter of 2018 to the third quarter of 2020, the average inventory balance of listed real estate enterprises in the southeast coastal areas basically increased steadily. This trend is consistent with the above theoretical derivation. In the short term, the price level of enterprise procurement will not change. Due to the decline of enterprise input tax, the purchase contract, which will be priced at a price excluding tax or the price including tax, will increase the enterprise 




FIgURE 3: Changes in business tax rates of sample companies.

TABle 2: Descriptive statistics of each quarter of each enterprise in 2018 and 2019.

\begin{tabular}{lcc}
\hline & Operating income in 2018 & Operating income in 2019 \\
\hline Average & 4793367851 & 5692121395 \\
Number of cases & 316 & 316 \\
Standard deviation & $1.51058 E+10$ & $1.84843 E+10$ \\
\hline
\end{tabular}

TABLE 3: Wilcoxon signed ranks test.

\begin{tabular}{|c|c|c|c|c|}
\hline & & $\mathrm{N}$ & Average value of rank & Sum of rank \\
\hline \multirow{4}{*}{ Operating income in 2019-operating income in 2018} & Negative rank & $140^{\mathrm{a}}$ & 149.84 & 20978.00 \\
\hline & Positive rank & $176^{\mathrm{b}}$ & 165.39 & 29108.00 \\
\hline & Binding value & $0^{c}$ & & \\
\hline & The total & 316 & & \\
\hline
\end{tabular}

aperating income in $2019<$ operating income in $2018 .{ }^{\mathrm{b}}$ Operating income in $2019>$ operating income in 2018. ${ }^{\mathrm{c}}$ Operating income in $2019=$ operating income in 2018.

TABLE 4: Test statistics ${ }^{a}$.

\begin{tabular}{lc}
\hline & Operating income in 2019-operating income in 2018 \\
\hline$Z$ & $-2.501^{\mathrm{b}}$ \\
Progressive significance (two-tailed) & 0.012 \\
\hline
\end{tabular}

${ }^{\mathrm{a}}$ Wilcoxon signed-rank test. ${ }^{\mathrm{b}}$ Based on negative rank.

procurement cost and compress the enterprise's profit space to some extent.

(3) Trends of Taxes and Fees Related to Operating Activities. In "taxes and surcharges," urban construction tax and education surcharges account for important proportions. They take value-added tax plus consumption tax as the tax basis, and value-added tax is the vast majority of them. Therefore, the changes in taxes and surcharges can reflect the changes in value-added tax burden to some extent. As mentioned above, the average operating income increases in general, which indicates that the tax basis of output tax increases.
However, it can be seen from Figure 6 that taxes and surcharges show relatively regular changes, increasing in 2019 compared with 2018 but falling back to a similar level in 2020, with little overall fluctuation. It means that the reduction of urban maintenance and construction tax and education surcharge under the value-added tax rate and the increase of sales tax caused by stimulating the growth of sales revenue have little impact on taxes and surcharges.

(4) Profit Trend. From the total profit changes of the sample enterprises shown in Figure 7, the profit changes of real estate enterprises have certain cyclical volatility. The 


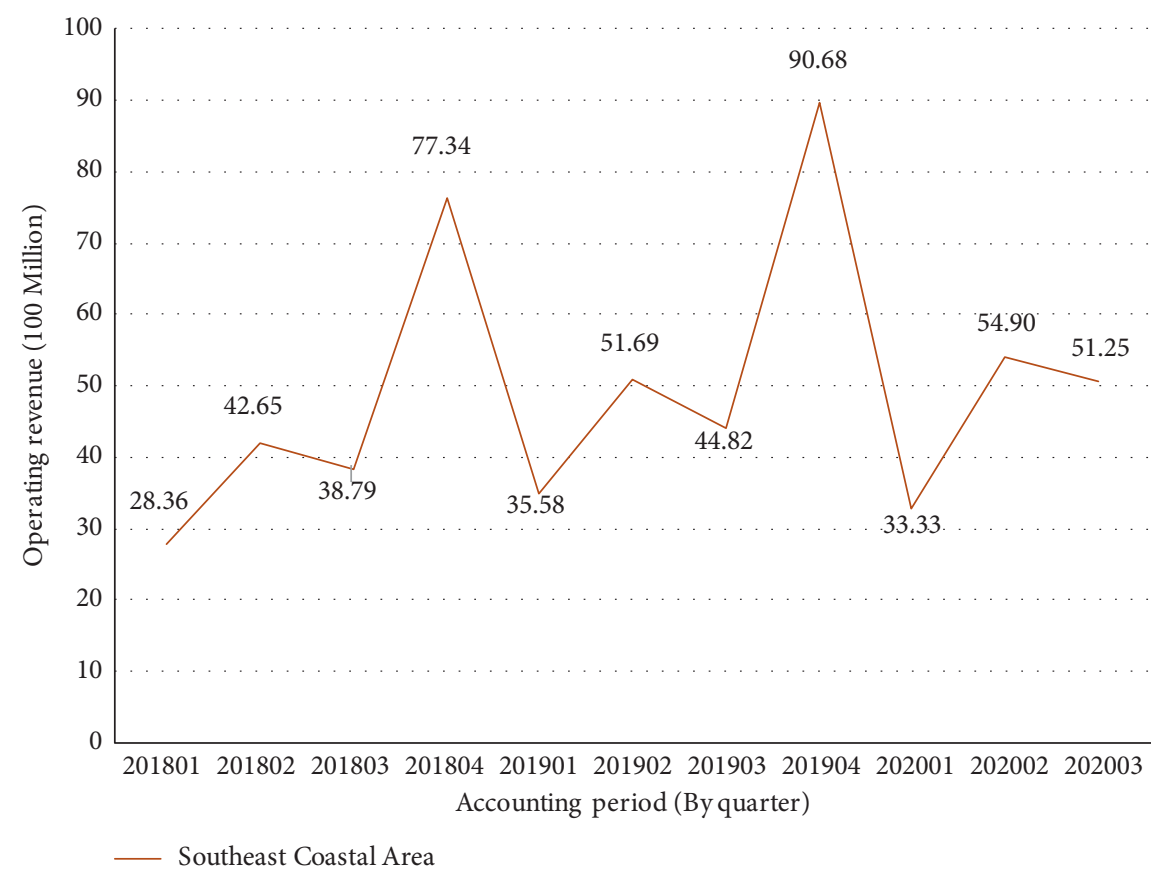

Figure 4: Changes in operating revenue of sample companies.

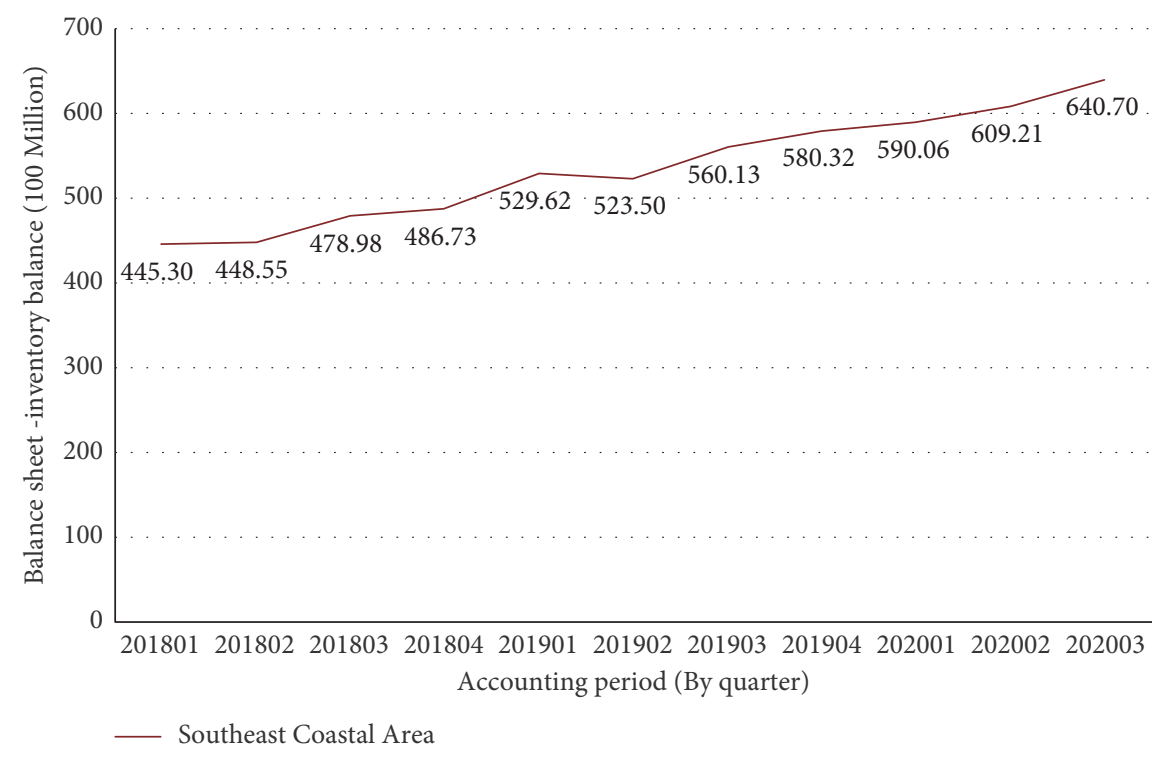

FIGURE 5: Changes in inventory balances of sample companies.

reduction of the value-added tax rate has had different effects on real estate enterprises in different regions. The total profits of real estate enterprises in Hainan and Fujian provinces did not increase but decreased or even were negative in the fourth quarter of 2019. It is speculated that the reduction in the purchase of fixed assets is due to the regional real estate policy. The input tax deduction and land decline of newly built real estate decreased significantly, which had a negative impact on enterprise profits. However, from the overall changes in the total profits of real estate enterprises in the southeast coastal areas, the reduction of the value-added tax rate on April 1, 2019, has a positive effect on the profit growth of real estate enterprises in the southeast coastal areas, and the total profits of enterprises show a cyclical upward trend. It shows that the reduction of output tax of real estate enterprises reduces the value-added tax actually paid by enterprises, reduces the total cost and valueadded tax burden of enterprises, and increases the total profit of enterprises.

(5) Cash Flow Trend. According to the statistics of the operating income of the sample enterprises from the first quarter of 2018 to the third quarter of 2020, the overall trend of cash inflow from operating activities shows a fluctuating 




FIgURE 6: Taxes and surcharges changes in sample companies.

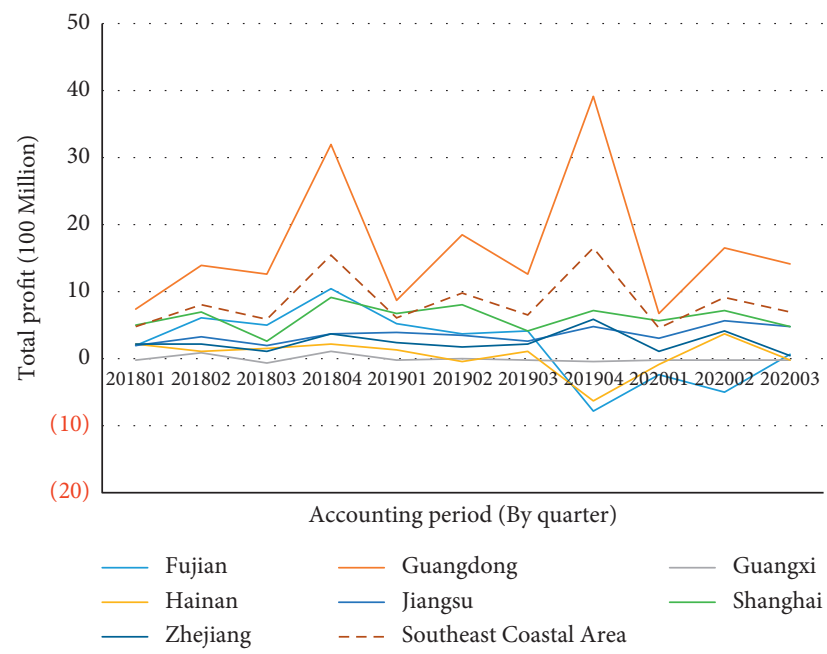

Figure 7: Changes in the total profits of sample companies.

rise in Figure 8, which has achieved a certain increase compared with the initial state. However, in the fourth quarter of 2019, the cash inflow experienced a sharp decline, and a minimum point appeared in the first quarter of 2020. This shows that the outbreak of COVID-19 in early 2020 reduced sales and investment activities to a certain extent, thereby reducing the inflow of cash. Therefore, it is speculated that the two large-scale tax reduction policies in 2018-2019 have improved the current situation of cash inflow of enterprises to a certain extent; In 2018, after the sample enterprises' cash flow expenditure decreased slightly, it began to rise slowly, while the average value of cash outflow from operating activities did not change much and basically remained at the original level. Therefore, it is speculated that the reduction of the value-added tax rate has no obvious change in enterprise cash outflow. Overall, the tax rate reduction still has a positive impact on enterprises. 


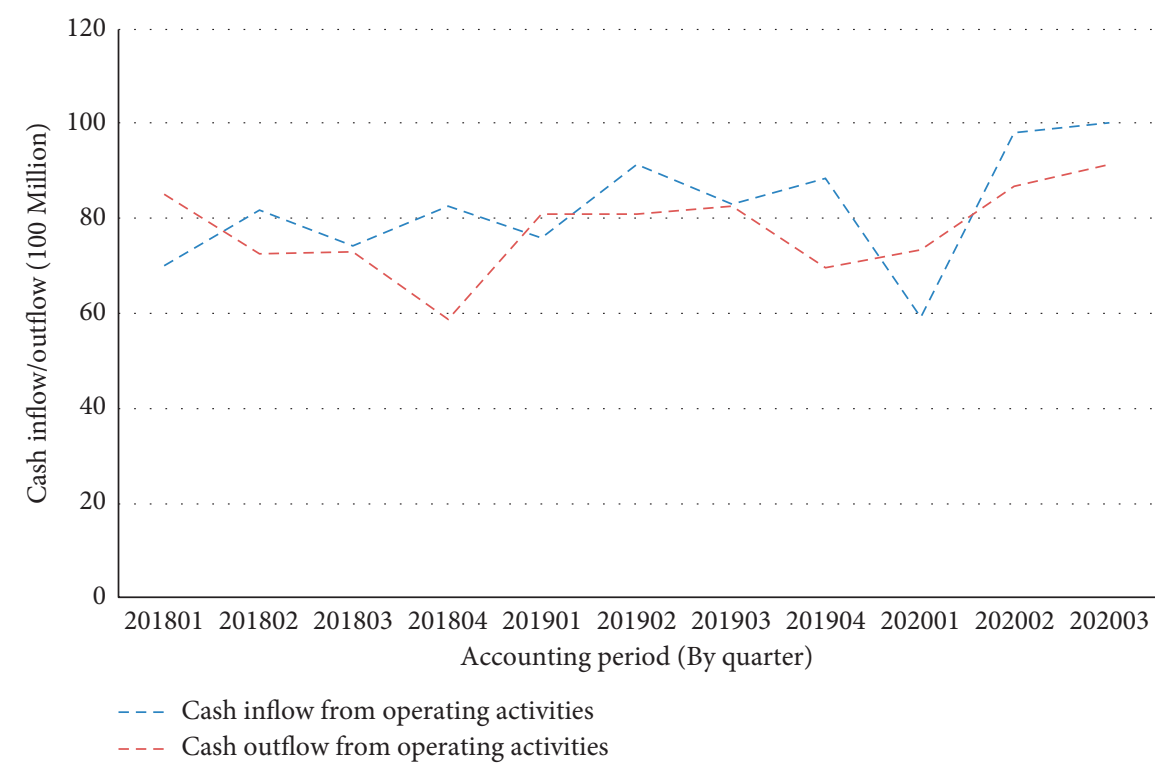

Figure 8: Changes in cash inflows/outflows from operating activities of sample companies.

\section{Conclusion and Suggestion}

4.1. Conclusion. The two reductions of the value-added tax rate have had an impact on listed real estate enterprises in the southeast coastal areas. The overall operating tax rate has shown a volatile downward trend; the average operating income level has shown a volatile upward trend; the purchase cost has decreased slightly and the change was not significant; the profit changes of real estate enterprises have had certain cyclical volatility. The reduction of VAT rate has had different effects on real estate enterprises in different regions, which has had a positive effect on the profit growth of southeast coastal real estate enterprises, and the total profit of enterprises has shown a cyclical upward trend. Due to the impact of the real estate purchase restriction policy and financing environment in recent years, the reduction of tax rate has had an effective but not significant impact on the enterprise cash flow. Overall, the tax rate reduction still has a positive impact on enterprises.

\subsection{Suggestion}

\subsubsection{Enterprise Level}

4.2.1.1. Scientific Tax Planning and Contract Management. In the procurement process, in order to make up for the reduction in deductible input tax to a certain extent, companies try their best to set the price excluding tax when signing the procurement contract, so that the final payment will be reduced. If a tax-included price is used for pricing, the company should make full use of the payment policy and other conditions to negotiate prices with suppliers and strive to reduce the contract price. At the same time, enterprises should scientifically choose the mode of cooperation with upstream construction enterprises and choose "labor and materials contracting" or "party a supplied project" in combination with their own situation, so as to better reduce the tax burden and increase profits.

4.2.1.2. Improve the Management Level and Establish an Industry Finance Integration System. Strengthen the management of inventories and fixed assets by formulating inventory analysis reports and sorting materials, reduce the reduction of deductible input tax, and increase of enterprise tax burden caused by abnormal losses of inventory and raw materials caused by poor management. Through establishing long-term cooperative relations with suppliers and intermediaries, improve the bargaining power in the industrial chain and enhance supply chain management, and improve the voice of enterprises in the process of contract signing. By making full use of the data resources and experience resources formed by the integration of business and finance, establish a perfect internal control system and information sharing system to integrate sales contract information, and purchase contract information and market information, so as to achieve the two-way promotion of "open source + throttling."

4.2.2. National Policy Level. The real estate industry is a major industry affected by macrocontrol. Due to the weak market demand and rising costs, enterprises are facing development difficulties. At present, the space for the decline of the value-added tax rate is limited, and the effect is also limited. The government should optimize the tax policy and give more tax relief policies directly, not only limited to value-added tax but also including the tax preference of corporate income tax.

\section{Data Availability}

The data used to support the findings of this study are available from the corresponding author upon request. 


\section{Conflicts of Interest}

The authors declare that they have no conflicts of interest.

\section{References}

[1] Y. Fan, H. Li, H. Li, and Q. Zhu, "Tax burden reduction and tax cuts in China's vat reform," Journal of Tax Reform, vol. 5, no. 1, pp. 23-41, 2019.

[2] K. Zhang, X. L. Lin, and Z. R. Fu, "Value added tax relief, enterprise tax burden and innovation input: an analysis based on 2013-2015 survey data," Commercial Research, vol. 59, no. 11, pp. 33-39, 2017.

[3] D. Dang, H. Fang, and M. He, "Economic policy uncertainty, tax quotas and corporate tax burden: evidence from China," China Economic Review, vol. 56, Article ID 101303, 2019.

[4] J. Cai and A. Harrison, The Value-Added Tax Reform Puzzle, National Bureau of Economic Research, Cambridge, MA, USA, 2011.

[5] A. Schenk, V. Thuronyi, and W. Cui, Value Added Tax, Cambridge University Press, Cambridge, UK, 2015.

[6] K. Ding, H. Xu, and R. Yang, "Taxation and enterprise innovation: evidence from China's value-added tax reform," Sustainability, vol. 13, no. 10, Article ID 5700, 2021.

[7] A. Howell, "Firm R\&D, innovation and easing financial constraints in China: does corporate tax reform matter?" Research Policy, vol. 45, no. 10, pp. 1996-2007, 2016.

[8] H. Fang, L. Yu, Y. Hong, and J. Zhang, "Tax burden, regulations and development of service sector in China," Emerging Markets Finance and Trade, vol. 55, no. 3, pp. 477-495, 2019.

[9] H. Huang, T. Wang, and Z. Zhan, "From business tax to valueadded tax: the effects of reform on Chinese transport industry firms," Australian Accounting Review, vol. 29, no. 1, pp. 158-176, 2019.

[10] W. Ai and S. Fan, "Empirical research on the effect of the business tax (BT) to value-added tax (VAT) reform on the financial performance of listed real estate companies," in Proceedings of the International Conference on Construction and Real Estate Management, pp. 219-225, Charleston, South Carolina, 2018.

[11] H. Fang, Y. Bao, and J. Zhang, "Asymmetric reform bonus: the impact of VAT pilot expansion on China's corporate total tax burden," China Economic Review, vol. 46, pp. S17-S34, 2017.

[12] Z. W. Tian and Y. J. Hu, "Dynamic analysis of effects of industry tax burden on the transformation from business tax to VAT-based on CGE model," Collected Essays on Finance and Economics, vol. 7, pp. 29-34, 2013.

[13] F. Zhou, "Effects and countermeasures of "Replacing Business Tax with VAT" to real estate industry," Modern Economy, vol. 7, no. 5, pp. 586-590, 2016.

[14] J. Du, Z. Wang, and Y. Yang, "Research on the impact of real estate industry's reform of replacing business tax for VAT on corporate financial efficiency-an empirical test based on DEA model," Journal of Guizhou University of Finance and Economics, vol. 36, no. 6, pp. 72-80, 2018.

[15] Y. Y. Liu, "Research on the significance of value-added tax amendment in 2019," in Proceedings of the 2019 4th International Social Sciences and Education Conference, pp. 407441, Xiamen, China, 2019.

[16] Y. M. Guo and Y. R. Shi, "Impact of the VAT reduction policy on local fiscal pressure in China in light of the COVID-19 pandemic: a measurement based on a computable general equilibrium model," Economic Analysis and Policy, vol. 69, pp. 253-264, 2021. 